\title{
“No Babies in Prison?" - Norway’s Exception Explained
}

\section{Introduction}

Babies can be accommodated by prisons to live with their mothers from new-born in many countries across the world. In fact, Norway is the only country that does not allow new-borns, babies or children in prison (Crewe, 2020 (a). In Germany young children can legitimately live with their mother in prison until the age of six, and in India children up to this age are imprisoned with their mothers without any pre-school education (Crewe, 2020(b). The age limit of children is different throughout the world and there is a lack of consistency with the treatment of this minority population. Mother and baby units are presented as a solution in the majority of countries however, these living arrangements are not always in the best interests of children (Crewe, 2020(c).

In many jurisdictions around the world there is evidence that international human rights for female prisoners have been violated. For example, it has been documented how there have been legal cases where women in prison have been fed rotten food or had no assistance when giving birth in their cell (Van-Gundy and Bauman-Grau, 2013). Conditions for women in prison can result from the implementation of programmes which fail to challenge the underlying health, social or welfare issues for women (Carlen and Tombs, 2006; Carlton and Baldry, 2013). Female prisoners are widely acknowledged to represent a population which has had a lifetime of discrimination, and is disproportionately represented by women who have been victims of abuse, poverty, substance misuse or have mental health problems (Corston, 2007; Knight and Plugge, 2005; Van Gundy and Baumann Gau, 2013).

There are 'no babies in prison' in Norway, however it is the dark side of this exception that is both interesting and difficult to adequately explain. Moreover, the human rights framework for pregnant women and babies in prison is still relevant for Norway. This article explains the paradoxical nature of Norway's exception with its detention of pregnant women in compulsory drug detention centres.

\section{The Human Rights Framework for Pregnant Women and Babies in Prison}

Human rights are applicable to all individuals who live in a prison, including babies. The Universal Declaration of Human Rights (1948), and the Vienna Declaration and Program of Action (1993), states that the foundation of freedom, justice and peace means recognising the inherent dignity and inalienable rights of all individuals (Birgden \& Perlin, 2009). International human rights for all prisoners are safeguarded through covenants such as the Convention Against Torture and Other Cruel Inhuman or Degrading Treatment or Punishment (1987) which gives freedom from torture or cruel, inhuman or degrading treatment. This universal legislation, in conjunction with regional and domestic legislative frameworks must guide the work of activists, practitioners and other stakeholders (Crewe, 2017).

The international level of governance has specific rules that relate to conditions in prison of pregnant women and babies. In 2010, The United Nations Rules for the 
Treatment of Women Prisoners and Non- custodial Measures for Women Offenders (the 'Bangkok Rules') were internationally adopted (United Nations General Assembly, 2011). The intention was for the Bangkok Rules to accompany the Standard Minimum Rules for Prisoners and other international or regional nonbinding treaties to form an international regulatory framework stating the conditions for women detained in secure institutions. In particular, the Bangkok Rules explain that for women with dependent children non-custodial sentences are preferred where possible. If this international human rights framework was implemented, then there is potential to significantly reduce the number of incarcerated women and babies (Crewe, $2020(d)$.

The Bangkok Rules (2010) are defined as a 'soft law', because there is no legal obligation for them to be incorporated into local contexts or practice. Despite this, for many scholars they have given hope for improving both prison regimes and the rights of female prisoners (Barberet, 2014; Carlen, 2013; Cain, 2015; Van-Gundy et al, 2013). Whilst the Bangkok Rules (2010) are not legally binding they provide seventy rules relating to the treatment of women and solutions such as: the development of sentencing alternatives to prison; rules which mean women's individual histories should be taken into account; and an important framework for overcoming violence of women within criminal justice systems. They are clear and specific about many issues relating to pregnant women, including the use of restraints (Crewe, 2017).

It is difficult to measure the levels of punitiveness across the world for pregnant women or babies in prison. The majority of studies have been conducted in the United States and focus on specialised programmes in mother and baby units (Barkauskas and Pimlott, 2002; Hotelling, 2008; Mason, 2013; Schroeder and Bell, 2005; Siefert and Pimlott, 2001; Williams and Schulte-Day, 2006; Wisemont, 2000). The first research that exclusively focused on pregnant women in prison was carried out between 1975 and 1982 and this used a medicalised discourse (Elton, 1988). Other studies have been carried out by midwives (Marshall, 2010; Price, 2005) or for a PhD qualification (Abbott et al, 2020; Chatten, 2013). Primary research conducted in prisons in England and Wales, has either linked pregnancy to mother and baby units (Corston, 2007; Children's Commissioner, 2008), mental health issues (Gregoire et al, 2010), or has mentioned pregnant women within a larger study (Eaton, 1993; Rowe, 2012). There have been two comparative studies that have focused on the differences for imprisoned pregnant women between England and Scotland (Eaton 1993; Dobash et al, 1986). Two studies have compiled international data about the number of pregnant women in prison (Robertson, 2007 and Barberet, 2014) and this research has assumed there are no pregnant women detained in Norway.

Alternative forms of detention for women can be invisible to regular monitoring, reporting of data or human rights organizations. Several nations have implemented alternative forms of detention for women, for example in Canada there are 'healing' lodges, and in the US 'half-way' houses. They are often hidden from mainstream knowledge, the media and politicians. These forms of detention do not necessarily 
use the criminal justice system for sentencing and have different types of personnel associated with them.

In Norway, incarcerated pregnant women are detained in what has broadly been defined as a compulsory drug detention centre (CDDC). A position paper published by the United Nations Office on Drugs and Crime (2012) is particularly critical of compulsory drug detention and it raises human rights concerns. The Norwegian Health and Care Services Act (Section 10-3) states that pregnant women can be admitted without their consent for the whole of their pregnancy. This form of detention is for women where substance abuse means that it is probable the child will be born with an injury. These places of detention for substance abusing pregnant women are called, 'Borgestadklinikken'. They are owned by the Blue Cross and are part of the private (non-profit) healthcare services. There are three centres that offer a range of services relating to addiction and substance misuse as well as residential accommodation for pregnant women. Norwegian research conducted about the incarceration of drug-addicted pregnant women is critical of legislation that is paternalistic and interventions that may be coercive for women (Soderstrom and Skolbekken, 2012). In particular, this study highlights how all forms of incarceration means there is a separation from partners, family and social networks (Soderstrom and Skolbekken, 2012).

\section{The 'Dark Side' of Norwegian Exceptionalism}

The Norwegian prison system is more liberal than other countries in the world. Pratt (2008) has described Norway as having exceptional prison standards of material comfort, relaxed prison atmosphere, the prison sentence being only the loss of liberty, and the principle of normalization. This exceptionalism thesis emphasises the underlying dynamic of a generous welfare state and the egalitarian nature of social organisation and cultural values. From this view, Nordic countries (Sweden, Norway, Denmark, Iceland and Finland) are more humane and have mild penal regimes because of their distinctive welfare states. Within the media this attitude towards male prison conditions can be illustrated where there are reports of, 'heated floors and pillow-top mattresses in prison' (Lieberman and Marales, 2018). This article claimed that Norway's prison system is designed with the three core values of: normality; humanity and rehabilitation (Lieberman and Marales, 2018).

The exceptional thesis explains that Norway's prisons have different regimes to other Western countries, but there are still rules, levels of surveillance, record-keeping, denials of choices, deprivations and sanctions (Pratt and Eriksson, 2012). This thesis has a bias towards making comparisons with English speaking countries that are prone to popular punitiveness or being cultures of control (Garland, 2001). In comparison to men, the standards for incarcerated women have been criticised. The Norwegian Parliamentary Ombudsman published a thematic report about the conditions for female prisoners in 2016. This uncovers the 'dark side' of Norway's prison system, where women have poor prison conditions. It stated that, "Overall, we have found many circumstances that place women in a worse situation than men and are breach of international standards" (Sivilombudsmannen, 2016). There are two 
prisons in Norway that are classified as mixed sex and one of them, Drammen Prison, is described as a cause for concern. It has been discovered that male and female prisoners have spent a lot of time together during work, school and leisure activities. Women reported unwanted attention and could potentially be subject to sexual harassment and abuse (Sivilombudsmannen, 2016).

Several women's prisons consisted of old and unsuitable buildings, poor access to outdoor areas or physical activities and there was consistently poor access to real work training (Sivilombudsmannen, 2016). The report claimed there was little recognition of healthcare for women, including mental health. Substance abuse rehabilitation services are inferior compared to men and the limited number of prison places means women are in a higher level of security. Women also serve sentences far away from their families and children. The Norwegian Parliamentary Ombudsman thematic report cited, "Women have special sanitary needs. The lack of toilets in cells and limited access to a shower for large parts of the day therefore represents a special problem for women" (Sivilombudsmannen, 2016).

Differences exhibited in Norway are notoriously difficult to explain and the 'dark side' of Norwegian exceptionalism can be described as a paradox. Barker (2012) explains the paradox of its Nordic penal regime as 'Janus-faced' because there is one side that is mild and benign and the other is intrusive, disciplining and oppressive. Similarly, other literature argues that the broad 'exceptionalism' literature needs to be reframed to take into account how Norway violates human rights (Fisher et al, 2014). Norwegian researchers criticise ethnocentric views and define oversimplifications as 'criminological tourism' (Zedner, 1995). The 'dark side' of the Norwegian culture is related to individuals who are unwilling or unable to conform and some prison researchers are particularly critical of the exceptionalism thesis by Pratt (2008) due to its characterisation of penal outcomes (Ugelvik and Dullum, 2012). Moreover, there is a need to be cautious about accounts that accept the penal rhetoric which describes prisons in Norway as 'liberal-humanitarian' (Leibling and Crewe, 2012). In the context of 'babies in prison', Norway is an exception because there are no mother and baby units. The reality and every day experiences are not known because literature that is available could be misread, oversimplifies the situation for detained pregnant women, and consists of thin or random material.

\section{Cultural Considerations for Detaining Pregnant Women in Norway}

Differences within Norway are explained as a cultural condition. In a revision of the thesis which explains Norway's exception, the role of religion has been cited as an explanation for differences from other Western societies (Pratt and Eriksson, 2012). The influence of the Lutheran Church has led to a secular nation with a strong relationship between the state and religion. The state has been instrumental in setting moral standards in a culture of extreme religious and racial homogeneity. Religious belief in the universality of $\sin$ and its temptations has historically encouraged government regulation because individuals could not be relied on to exercise self-control (Pratt and Eriksson, 2012). In the past alcohol prohibition was actioned by the state and recently the vision of a 'drug-free' society justifies intrusive 
practices, even if dignity is forced onto individuals (Barker, 2012). Cultural or ethnic difference leads to conditions where those cast as 'outsiders' are subject to the intrusive uses of state power (Barker, 2012).

The attitude of many countries in Scandinavia towards drugs is known to be more proactive and intrusive than other Western countries. Research has shown that whilst countries such as Sweden have a smaller number of drug crimes reported to the police, prison populations are mainly drug users (Barker, 2012). For male prisoners the exceptionalism thesis explains that whilst there are fewer prisoners per capita and shorter sentences, the maximum penalties for drug crimes are strict (Pratt and Eriksson, 2012). There are many practices cited by Barker (2012) that challenge a mainstream understanding that Norway has mild penal sanctioning and human rights protection. These practices include the over-representation of foreign nationals in prison, the deportation of children, the compulsory treatment of drug addicts and alcoholics as well as the imprisonment of drug users (Barker, 2012).

This intrusive state power can be illustrated in its justification for detaining substance using pregnant women to protect the unborn child from Foetal Alcohol Syndrome as a result of drug or alcohol abuse. Norway is the only country in Europe that has legislation authorising the detention of pregnant women to protect the foetus called 'detention of pregnant substance abusers', revised in 2011 and known in Norway as paragraph 10:3 (Sovig, 2012; Ministry of Health and Care Services, 2011). Women are detained in places that are colloquially referred to as 'clinics' (Soderstrom and Skolbekken, 2011;2012; Sovig, 2012). The largest is called, 'Borgestadklinikken' and managed through a contract by the Norwegian Blue Cross South who state, 'they are 'inspired by Christian values and a holistic view of the human being' (accessed August 2020).

\section{Coercion from Norwegian medical professionals}

Norway is a Scandinavian country that has received criticisms for its protective state. In comparison to Western Europe, post-1945 Scandinavian countries were unique in their use of compulsory sterilization and castration laws (Pratt and Eriksson, 2012). These sterilisation and eugenic programs were eventually abolished in the 1970's. The reason why these practices were authorised is tied to the investment of power in a strong central state, a high value on expert knowledge as well as preventing individuals from challenging social cohesion or homogeneity (Pratt and Eriksson, 2012).

Medical professionals have been criticised for restricting the autonomy of pregnant women and since the 1970's and 1980's feminists have used the concept of medicalization to explain how a range of professionals control women. Feminist literature highlights how choices for pregnant women are linked to their autonomy and dominant discourses in society. Research concerning pregnancy in prison has found that women with complex medical issues have difficulties accessing services and receiving appropriate care (Albertson et al, 2012; Price, 2005).

Coercion is known to have impacted the choices and access of services for women, especially with pregnancy and childbirth. The high investment of expert knowledge 
and power of the state has led to a situation where it is possible for health care professionals to override a woman's decision about her pregnancy. Coerced treatment in Norway is justified through a culture where substance-addicted women are generally not trusted to take care of their children (Soderstrom and Skoldbekkn, 2012). The combination of pregnancy, addiction and legislation that authorizes medical professionals to detain women is problematic.

Unlike the sterilisation programs, the 'dark side' to the involuntary detention of substance abusing women is not widely known about. This practice of state authorised coercion against women to protect the foetus has received criticisms from Norwegian academics (Sovig, 2012, Soderstrom and Skolbekken, 2012). They highlight a moral and ethical dilemma which concerns the outcome of coercive medical professionals. The Norwegian legislation is justified to protect the foetus however it is possible that substance abusing women could choose to have an abortion rather than be detained involuntarily (Sovig,2012). This legislation links to a wider ethical debate about the choice and timing of abortions for women. It reflects a religious pro-life and anti-abortion discourse that advocates the protection of the foetus rather than supporting women. Research within England and Wales has considered the support women may need with making an abortion decision and explains that making women wait is problematic because it puts their health at further risk (Hoggart, 2015; Rowlands, 2008). It is not known how many women choose to have an abortion rather than continue with their pregnancy in detention by a clinic.

\section{Human Rights Considerations for Norwegian Detention of Pregnant Women}

Norway has been categorised with other Nordic states as a 'moral superpower' (Dahl, 2005), 'agents of a world common good' (Bergman, 2007) or 'global good Samaritans' (Brysk, 2009). These descriptions capture the role of Norway and other countries in the Nordic region, such as Sweden, or Finland, in their mediation and peace-keeping efforts, high levels of foreign aid and standing in global affairs. Traditionally, Norway has not organised access to benefits and services provided by the welfare state as an individual legal entitlement or right (Tragardh,1999). Norway has ratified international treaties however there is a lack of knowledge about domestic performance and international commitment.

The human rights framework for pregnant women in detention is complicated because the Bangkok Rules implicitly assume that women are detained in prisons and have access to legal procedures (Crewe, 2017). In relation to the legislation within Norway, there is no sentencing procedure or access to a judicial review. This lack of individual rights has not been addressed in the exceptionalism thesis by Pratt (2008) or the revision (Pratt and Eriksson, 2012). There are many gaps in knowledge, especially for societies that are characterised as having mild penal sanctioning (Barker, 2012). Furthermore, this means that whilst Norway appears to promote and provide human rights, for some populations the lack of individual rights can lead to domestic policies and practices that have the potential to violate human rights. 
There is an added complication in relation to the current Norwegian legislation that sanctions medical practitioners with making decisions to involuntary detain substance-abusing pregnant women and this is the complex philosophical and moral dilemma concerning the rights of an unborn child and their pregnant mother. According to some academics, the pre-amble to the Declaration of the Rights of the Child (1959) was the first instrument to focus on legal protection before birth (Westra, 2006; Joseph, 2009). Morally, there are complex issues concerning the rights of pregnant women because when babies are born their rights are protected using the Convention for the Rights of Children. The unintended consequence of protecting unborn children reduces a mother's needs and women simply become a 'vessel'. Moreover, once the child is born there is a conflict between the rights of children and their best interests if they are separated from their mother at birth.

\section{Conclusion}

The practice of allowing babies to stay with their mothers in prison appears to support both women and their children. The human rights framework is complex however the addition of the Bangkok Rules means there is clarity for the detention of pregnant women and babies. Within this framework there is enough scope for it to protect the practice of detaining pregnant women within healthcare 'clinics' in Norway.

There is no ideal solution. The legislation in Norway highlights the complexity of allowing healthcare professionals the power to decide to detain pregnant women. This legislation has been introduced in a country known for its maintenance of religious values, intrusive moral practice and control of populations who don't conform. It is known that Norway has a history of encouraging sterilisation or castration through coercion and the implementation of legislation. It is concerning that women in Norway could be subject to coercive medical practices which mean they are forced to make a decision whether to have an abortion or be detained involuntarily and with no recourse to a judicial review.

Data is deceptive. International comparisons highlight the number of prisoners in a country. There are no babies in prison, so therefore it could be assumed that there is no need to be concerned about research for women in prison. This article explains the value of the Norwegian exception thesis, despite its shortcomings in its lack of explanation about details. Significantly it is important to ask: why are there no babies in prison? 


\section{References}

Abbot, L, Scott,T, Thomas, H and Weston, K (2020) Pregnancy and childbirth in English Prisons: institutional ignominy and the pains of imprisonment Sociology of Health and Illness Vol 42: No 3

Albertson, K, O'Keeffe, C, Lessing Turner, G, Burke, C and Renfrew, M. (2012) Tackling health inequalities through developing evidence-based policy and practice with childbearing women in prison: a consultation: partnership between the Hallam Centre for Community Justice, Sheffield Hallam University and The Mother and Infant research unit, Department of Health sciences, University of York.

Barberet, R. Women, Crime and Criminal Justice: a global enquiry. (2014). New York: Routledge.

Barker, V (2012) Nordic Exceptionalism revisited: Explaining the paradox of a Janus-faced penal regime Theoretical Criminology Vol 17:5

Cain, C (2015) State of the estate: women in prison's report on the women's custodial estate (2nd ed.). Retrieved from http://www.womeninprison.org.uk

Carlen, P and Tombs J (2006) Reconfigerations of penality, the ongoing case of the women's imprisonment and reintegration industries Theoretical Criminology, Vol 10 (3): $337-360$

Carlen, P (2013)." Preface." In Carlton, B and Segrave, M. (Eds). Women Exiting Prison: Critical Essays on Gender, Post-Release Support and Survival. Oxon, UK: Routledge.

Carlton, B., \& Baldry, E. (2013). Therapeutic correctional spaces, trans-carceral interventions: postrelease support structures and realities experienced by women in Victoria, Australia. In B. Carlton\&

M. Segrave(Eds.), Women exiting prison: Critical essays on gender, post-release support and survival. Oxon, UK: Routledge.

Chatten, P, (2013). Pregnant and in prison: can the quality of services provided affect the overall perception of being pregnant? Plymouth Law and Criminal Justice Review retrieved April 2013

Children's Commissioner. (2008), '11 Million', Prison mother and baby units - do they meet the best interests of the child? Retrieved from www.1MILLION.org.uk November 2012

Corston, J. (2007) The Corston Report: A Report by Baroness Jean Corston of a Review of Women with Particular Vulnerabilities in the Criminal Justice System, London: Home Office.

Crewe, B and Liebling, A (2012) Are liberal-humanitarian penal values and practices exceptional? in Ugelvik, T and Dullum, J (2012) Penal Exceptionalism? Nordic prison policy and practice Oxon: Routledge 
Crewe, H (2017) "Can Therapeutic Jurisprudence Improve the Rights of Female Prisoners?" in Halder, D and Jaishankar, K. Therapeutic Jurisprudence and Overcoming Violence Against Women IGI Global

Crewe, H. (2020 (a) When the Pendulum is stuck! - Invisible Agonists and Babies in Prison. Cambridge Open Engage. doi:10.33774/coe-2020-nkn75

Crewe, H (2020(b) Female Prisons Around the World: Facts and Figures about Women in Prison, LAP: Lambert Academic Publishing.

Crewe, H (2020 (c) Putting Babies First - Supportive Choices for Mother and Baby Units Open Engage https://www.cambridge.org/engage/coe/articledetails/5f762c52a70f3600190e51eb

Crewe, H (2020 (d) Neo-Liberal Governmentality and Babies in Prison Cambridge Open Engage. https://doi.org/10.33774/coe-2020-6v81b

Dobash, R.P, Dobash, R.E and Gutteridge S (1986) The Imprisonment of Women, Oxford: Basil Blackwell Ltd

Eaton, M (1993) Women after prison, Open University Press.

Elton, P. (1988) Mothers and babies in prison, British Journal of Hospital Medicine, Vol: 40, No 9.

Garland, D (2001) The culture of control: crime and social order in contemporary society. Oxford: Oxford University Press.

Hoggart, L (2015) Abortion counselling in Britain: understanding the controversy Sociology Compass: $9 / 5$

Hotelling, B (2008) Perinatal needs of pregnant, incarnated women, The Journal of Perinatal Education, Vol 17: No 2

Knight, M, and Plugge, E. (2005). Risk factors for adverse prenatal outcomes in prison: A systematic review. BMC Public Health, 5(1), 111. doi:10.1186/1471-2458-5-111 PMID:16229740

Lieberman, D and Morales, C (2018) 'Heated floors and pillow-top mattresses... in prison accessed on 23 October 2020 from https://edition.cnn.com/2018/03/08/us/prison-reformnorth-dakota-norway/index.html

Marshall,D (2010) Birth Companions: working with women in prison giving birth, British Journal of Midwifery: Vol 18, No 4.

Mason L (2013) The journey of one pregnant incarnated woman through systemic bias: How Family Support Workers can positively affect change- a case study

Pratt, J (2008) Scandinavian exceptionalism in an era of penal excess: part 1: the nature and roots of Scandinavian exceptionalism

Pratt, J and Eriksson, A (2012) In defence of Scandinavian Exceptionalism in Ugelvik, T and Dullum, J (2012) Penal Exceptionalism? Nordic prison policy and practice Oxon: Routledg 
Price S (2005) Maternity services for women in prison: a descriptive study, British Journal of Midwifery, Vol: 13 No 6.

Robertson, O (2008) Children imprisoned by circumstance Quaker United Nations Office: Human rights and refugee's publications.

Rowlands, S (2008) The decision to opt for abortion Journal of Family Planning and Reproductive Health Vol 34: 3

Schroeder C and Bell J (2005) Doula Birth support for incarnated pregnant women Public Health Nursing, Vol: 22 No: 1

Siefert, K and Pimlott, S (2001) Improving pregnancy outcome during imprisonment: a model residential care program, Social Work, Vol 46 (2)

Sililombudsmannen (2016) Women in Prison: A thematic report about the conditions for female prisoners in Norway Norwegian Parliamentary Ombusman

Soderstrom, K and Skoldbekken, J (2012) Pregnancy and substance abuse - the Norwegian $: 10-3$ solution. Ethical and clinical reflections related to incarceration of pregnant women to protect the foetus from harmful substances, Nordic studies on Alcohol and Drugs, Vol 29.

Sovig, K H (2012) Detention of pregnant women to protect the foetus - Nordic perspectives in Rynning E and Hartlev M (2012) Nordic health law in a European Context published by Martinus Nijhoff.

Williams L and Sculte-Day S (2006) Pregnant in prison - the incarnated woman's experience: a preliminary descriptive study Vol 12: No 2

Wisemont J (2000) The lived pregnancy experience of women in prison Journal of Midwifery and Women's Health, Vol: 45 No: 4.

Ugelvik, T and Dullum, J (2012) Penal Exceptionalism? Nordic prison policy and practice Oxon: Routledge

United Nations General Assembly. (2011). Resolution adopted by the General Assembly: 65/229 United Nations Rules for the Treatment of Women Prisoners and Non-custodial Measures for Women Offenders (the Bangkok Rules). Sixty-fifth session: agenda item 105.

United Nations Office on Drugs and Crime (2012) UNODC and the promotion and protection of human rights position paper

Van Gundy, A and Buamann-Grau, A. (2013) Women, incarceration and human rights violations Ashgate Publishing Company, Farnham, Surrey and Burlington, USA.

Zedner, L (1995) In Pursuit of the Vernacular: Comparing Law and Order Discourse in Britain and Germany Social and Legal Studies: Sage 
Helen Crewe: 23 October 2020. 